\title{
Occupy in One Classroom
}

\author{
By Ira Shor
}

2 011 was an historic year of global protests. Here in New York, the Capitol of Capital, Occupy Wall Street (OWS) sustained a rebel encampment for 59 days at now-famous Zuccotti Park in the financial district. Hundreds of other occupations erupted around the United States and abroad. Occupy activists declared "Another world is possible!" and set out to build it in a small concrete park.

Popular with large segments of the American public, OWS garnered deep material, financial, and political support which helped it through weeks of police beatings, harassments, and arrests, as well as the early onset of wet and cold

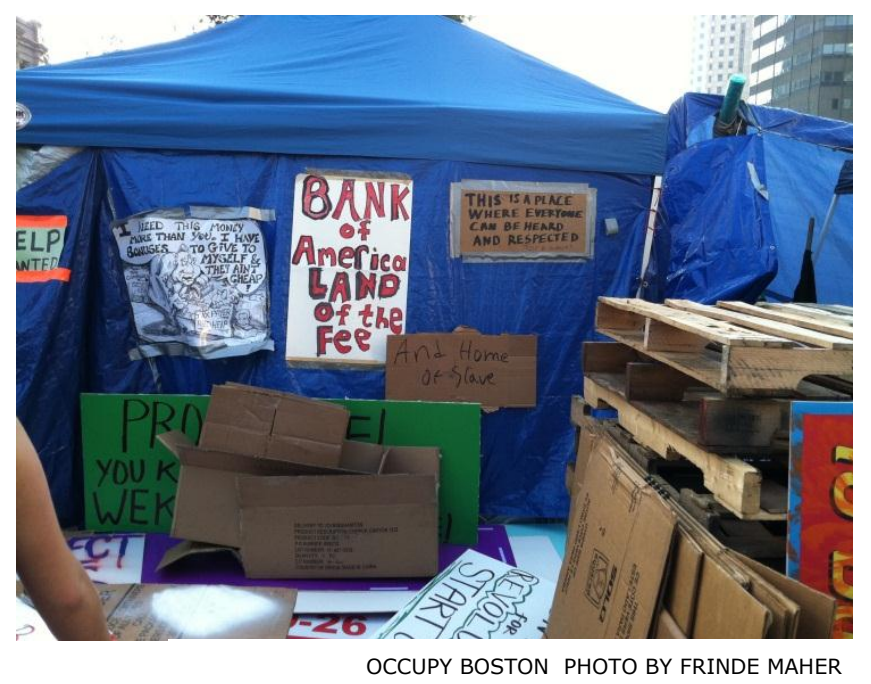

political world upside down for 59 days until November 14 . Then, billionaire Mayor Michael Bloomberg ordered a massive police assault after midnight to destroy the stillevolving camp. Sanitation workers hauled away its remains. Most camps elsewhere were similarly liquidated to disperse and silence the consolidated protests in central city squares.

Decapitated from its signature site, OWS morphed into Occupy 2.0, testing multiple campaigns: supporting immigrant workers on strike at a local bakery, protesting the arrival of hydraulic "fracking" to extract natural gas, publishing a free Debt Relief Operations weather. In those weeks, OWS and Occupy nationally forced into public debate forbidden themes of vast economic inequality, sleazy gambits of financiers, and complicit politicians who bailed out despised bankers with $\$ 7$ trillion in taxpayer funds. In New York City, daily marches, assemblies, videos and non-stop teach-ins became a growing challenge to the legitimacy of the state and corporate system. Week to week, OWS shone an unflattering spotlight on ignored needs of "the $99 \%$ " and on financiers who do business in the shadows. The brilliant chant "We Are the 99\%!" helped coalesce disparate folks abused by the $1 \%$. "The Party of Capital" as David Harvey calls the $1 \%$ was on the defensive, losing the war of words and representations.

Unauthorized and creative, struggling to keep up with waves of new participants and new occupations, pressured to enact its own democratic ideals, OWS turned the
Manual, allying successfully with other New Yorkers to demand that the Mayor cancel the Marathon and use its lavish resources to help stricken neighborhoods after Hurricane Sandy, and so on.

Like many teachers, I made Occupy a classroom theme. These notes report on my Fall 2012 seminar 'Mic Check': Rhetoric and Resistance In/After "Occupy" at the City University of New York Graduate Center. As I write, we are halfway through the term.

Last Spring, 2012, I published a description of the seminar for the upcoming Fall registration:

"In the late $20^{\text {th }}$ century, Vaclav Havel exhorted idealists to speak truth to power. Playwright and politician, Havel proposed that democratic discourse could undermine undemocratic oligarchies. Such dreams and discourses moved millions to bury the crony regimes of Eastern 
Europe. Thus continued a remarkable history of non-violent transformation which can trace its roots to the Ghandian campaigns before 1948 in India and to the great American Civil Rights Movement in the U.S in the 1950s-1970s. Confronting entrenched and armed oligarchies is formidable anywhere, yet the weapons of rhetoric have been strangely enabling in democratic struggles. Opposition movements have undermined the 'regimes of truth' and the 'legitimate language' which Foucault and Bourdieu separately named as discursive tools for domination. A bevy of police states from the Baltic to the Adriatic fell by 1991 . More recently, an Arab Spring spread across borders with some spectacular successes and some major setbacks, with the Egyptian story heavily-marked by communications strategies. Then, in September, 2011, a handful of creative activists physically occupied Zuccotti Park near Wall Street, encamping in a tent village, launching an 'Occupy Movement' in the Capitol of Capital. For two months, the village morphed into new expressive shapes, attracting tens of thousands to witness if indeed 'another world is possible,' one that challenges the vast economic inequality damaging American life. By the time the Occupy camp was destroyed by a violent police assault in November, it had become an intolerable built challenge to the legitimate authority of Wall Street and the oligarchy represented by billionaire Mayor Michael Bloomberg. The camp embodied, uttered and projected alternative ways of being and seeing, and was an incubator of alternative rhetoric. Among the alternatives practiced in this transformative space were 'horizontal' social relations. A horizontal rather than a vertical rhetoric structured its meetings. Open general assemblies operated horizontally with rotating chairpeople and with 'stacks' to determine speaking order based on social power of speakers, that is, who speaks most and least in such public spheres, which individuals and groups were socially ascribed lesser or greater authority to speak in public(challenging what Paulo Freire called 'the culture of silence'). Occupy also generated autonomous working-groups which copied the horizontal structure of the general assemblies. Most notable, perhaps, Occupy also installed 'the human microphone' as a public-address system. Denied legal use of sound-amplification at Zuccotti by the police, general assemblies and other large meetings practiced group repetition of a speaker's remarks in a now-famous choral method. The human microphone also emerged as a tool for assertion of utterances at public protests where an individual's call of 'mic check!' assembled the human microphone for amplification as well as for relaying instructions. With Occupy camps now driven out of public spaces, this seminar will study horizontal discourse and rhetorical resistance emerging from the protests."

The seminar filled to capacity (12) on the first day of registration in May. I had been following OWS online, in print, and onsite since it began, and had a file and shelf of materials. My summer reading also provided useful titles for the syllabus, far more than could fit in one course. I sought articulate first-person accounts from participants in the general assemblies, working groups, and protest actions along with analytic and historical texts on the deep economic and ideological background of the famous eruptions of 2011 . The syllabus below reflects these criteria. Often undecided about this text or that, I put the syllabus through multiple versions, changing it again after the seminar began. (One change was apparently one too many: a student objected and others supported her, so I withdrew it.) Here is a late iteration of the syllabus; it changed again when Hurricane Sandy closed the City for a week:

'MIC CHECK': RHETORIC AND RESISTANCE IN/AFTER "OCCUPY"

THURS: 6:30-8:30, PROF. IRA SHOR

\section{READINGS:}

Debt: The First 5,000 Years, David Graeber, Melville House Publishers.

Declaration, Michael Hardt and Antonio Negri, Argo/Navis Author Services.

Domination and the Arts of Resistance, James C. Scott, Yale UP.

Occupy, Noam Chomsky, Occupied Media Pamphlets, Zuccotti Park Press.

Occupy Nation: The Roots, the Spirit, and the Promise of Occupy Wall Street, Todd Gitlin, itbooks/HarperCollins.

Occupying Wall Street: The Inside Story of an Action that Changed America, Writers for the 99\%, Haymarket Books.

Rebel Cities: From the Right to the City to the Urban Revolution, David Harvey, Verso.

The Leaderless Revolution: How Ordinary People Will take Power and Change Politics in the $21^{\text {st }}$ Century, Carne Ross, Blue Rider Press/Penguin. Books.

The Occupy Handbook, Ed. Janet Byrne, Back Bay

This Changes Everything: Occupy Wall Street and the 99\% Movement, Ed. Sarah van Gelder, Berrett-Koehler Publishers.

Voices from the 99 Percent: An Oral History of the Occupy Wall Street Movement, Ed. Lenny Flank, Black and Red Publishers.

\section{SCHEDULE}

Aug. 30: INTRODUCTION: "Occupy, Rhetoric, Resistance"

Sept. 6: Excerpts: "What is Rhetoric?"; Raymond Williams on "Hegemony," "Ideology," and "Signs and Notations"; Derek McGee, "The Occupied and the Occupier"; David Graeber, "Can Debt Spark a Revolution?".

Sept. 13: Occupying Wall Street, Writers for the $99 \%$, $1-143,168-202$.

Sept. 20: This Changes Everything, van Gelder, 1-84; Chomsky, Occupy, 23-103.

Sept. 27: Voices from the 99 Percent, Allison Nevit/Una Spenser Posts, 45ff, 50ff, 57ff, 69ff, 92ff, 
102ff, 131ff, 143ff, 176ff, 208ff, 303ff; Graeber, "On Playing by the Rules: The Strange Success of OccupyWall Street," 272-284.

Oct. 4: The Occupy Handbook: Cassidy ("What Good is Wall St.?"); Acemoglu/Robinson ("Against Political Capture"); Graeber("Occupy Wall St.'s Anarchist Roots"); Greenberg("On the Meaning of Occupation"); Lustig et al.("Basta Ya!"); Goodman/Moynihan("Occupy the Media"); Solnit("Civil Society at Ground Zero").

Oct. 11: Negri, Hardt, Declaration, 1-108, Ehrenreich and Ehrenreich ("The Making of the American 99\% and the Collapse of the Middle Class"). 1-107.

Oct. 18: Scott, Domination and the Arts of Resistance,

Oct. 25: Scott, Domination, 108-227.

Nov. 1: Harvey, Rebel Cities, Section 1.

Nov. 8: Harvey, Section 2.

Nov. 15: Graeber, Debt, Chaps. 5, 6, 7 (89-211), Chaps. 11,12 (307-391).

Nov. 22: NO CLASS. THANKSGIVING.

Nov. 29: Ross, Leaderless Revolution, Preface and Chaps. 4, 7, 8, 9.

Dec. 6: Gitlin, Occupy Nation, 1-231.

Dec. 13: SYMPOSIUM, final reflections due.

The title and academic perspective of 'Mic Check': Rhetoric and Resistance In/After "Occupy" fit my composition/rhetoric appointment to the English Ph.D. Program at CUNY. My plan was to use rhetorical theory and analysis to explore Occupy's oral, textual, and spatial discourses. Progressives in a variety of academic fields could of course teach about Occupy within other academic frames.

\section{I propose that discourse is a material force for the social construction of human subjects. We become human subjects of a certain kind depending on kinds of rhetoric and discourses directed at us.}

On the first night of the seminar, students introduced themselves, their work at the grad school, what they wanted to learn about Occupy, where they teach, etc. None had studied rhetoric per se, so I handed out definitions of rhetoric from mainstream scholars, including brief historical summaries of rhetoric's origins in Greece 2500 years ago. After reviewing this material, I proposed my own framework for "rhetoric and discourse" synthesized from multiple sources (Dewey, Freire, Burke, Foucault, Bourdieu, and contemporary scholars like James Berlin, Sharon Crowley, John Trimbur, and Richard Ohmann). My compact definition reads like this: "Rhetoric involves the production, circulation, reception, and interpretation of meaningful discourse broadly conceived." I offered it as a statement of functional elements we would apply to specific OWS actions and texts, as well as to actions by various corporate and political authorities in society. To make the four elements concrete, I handed out news stories from media sources to show "production, circulation, reception, and interpretation" in actual situations and specific events.

Next, I proposed a relation between "rhetoric and discourse" along these lines:

Rhetoric enables us to compose discourses because it is a framework of productive rules, techniques, and guides for generating communication for actual settings, real audiences, in-progress tasks, and articulated purposes. Because we communicate in diverse settings to different audiences with various purposes requiring distinct forms of address, we learn to use multiple rhetorics which enable us to generate appropriate discourses for particular circumstances. Discourses, then, are specific acts of meaningful communication. Rhetoric is a toolbox (often tacit, sometimes explicit) we use for composing discourses to fit any setting and purpose. Discourses built from the tools of rhetoric applied to some kind of expressive material (words, paint, song, etc.) become social tools of communication we use to act in, on, with, or against any setting.

Conceptual statements like these are appropriate for a graduate seminar, but even there they require study and discussion of concrete examples, which I foster through frequent email exchanges as well as in class. I hand out many media stories for cognitive work that follow Paulo Freire's call to "read the world and the word" together, the printed or spoken word as they reveal the nature of experience and power relations in society. I also provide concrete illustrations to elaborate the phrase "meaningful discourse broadly conceived": the discourses we can compose from our rhetorics may take any number of forms in various genres and materials: verbal (spoken utterances, speech acts), textual (hand-written, printed, or online), enacted (body language, facial expressions, hand gestures), visual arts (dance, photography, painting, sculpture, architecture), musical (vocal, instrumental, live or broadcast or recorded), performative (mime, spoken word, film and theater which include speech, props, movement, musical effects), spatial (insofar as exterior streets, roads, houses, buildings, parkland, plazas, display ads, etc., and the interior domains of furnished spaces send messages which are pedagogical), and embodied (because our physical bodies "speak" and can be "read" as discourses relating to gender, race, class, body size (vis a vis size, shape, age, wardrobe, tattoos, piercings, accessories, hair, makeup, posture, teeth, etc.).

In short, I invite thought about rhetoric as an historic invention of communication which enables us to compose specific and diverse discourses for actual situations and intentions using the materials at hand (as Aristotle put it). Yes, rhetoric is a civilization-altering tool which is also a means for composing self and society. When we use rhetoric to compose discourses, we are also composing ourselves as agents in the world while also composing the world we are acting in. 
I propose that discourse is a material force for the social construction of human subjects. We become human subjects of a certain kind depending on kinds of rhetoric and discourses directed at us (which Bourdieu called "the habitus") and which we use in the situations of our lives (which Bourdieu called "fields"). Consciousness is built by our serial experience in discourses.

If rhetoric generates discourses with the power to constitute us as certain kinds of human beings who then constitute their society by our choices and actions, we can ask questions important for understanding the Occupy movement: How do Occupy's discourses differ from those of dominant society? How do Occupy's signifying practices work from alternate rhetorics? Can the discourses of Occupy re-compose us into different human subjects from those produced by mainstream discourses always already composing us?

A final foundational notion I introduce involves the role of rhetoric and discourse in modern state formation, especially valuable because 2011 saw mass (unarmed, non-violent) resistance confronting the (heavily-armed, violent) state. Around 1500, European nobility began consolidating kingdoms into large states which concentrated enormous wealth and power in the hands of elites who used their assets to dominate at home and to launch global conquest abroad. For this seminar on Occupy, I suggest a central role for rhetoric in defining minimal conditions for successful state formation: A state is a geographical space with a contiguous border which a dominant group can defend from within against competing groups and from without against foreign forces

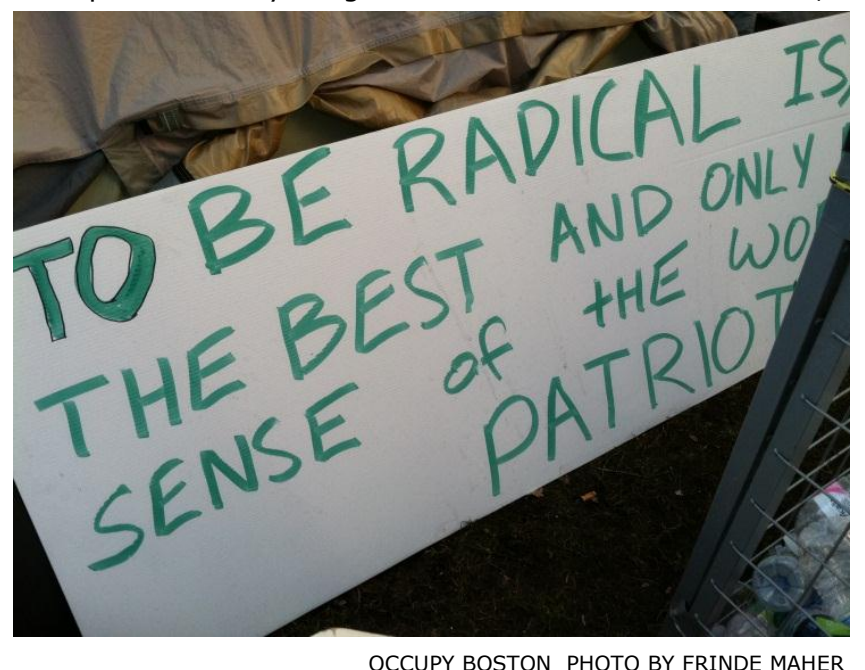
by monopolizing internally the instruments of violence and the instruments of representation.

Rhetoric and discourse (like mass media and formal schooling) belong to the "instruments of representation"; they signify meanings, explain events, inculcate ways of seeing and being, legitimize some values and groups while discrediting others, influencing how we know what is good, what is possible, and what exists (to use Goran Therborn's framework). Noting how important discursive tools like books, plans, documents, and maps were to European conquest, Jared Diamond called writing the most important invention of the last 3000 years(in Guns, Germs, and Steel). To make this function of discourse tangible, I provide-in class and via email-a stream of current news articles about situations in which state and corporate groups as well as oppositional groups use discursive means to their advantage in power struggles. In 'Mic Check': Rhetoric and Resistance In/After "Occupy", we considered how OWS threatened the corporate-state monopoly on instruments of representation, producing and circulating oppositional texts and images which gained mass audiences for critical politics. Competing suddenly and effectively with official discourses, OWS made egalitarian, anti-finance values loudly credible for 59 days.

With the class in progress as I write, conclusions about the pedagogy are premature. We have been reading books, essays and chapters weekly, for which I ask each student to hand in a journal excerpting a section of the reading and commenting on it. In each class, students nominate pages we should begin with for discussion. Just before this student choice, I hand out from one to five media illustrations of my notions above and those proposed by the authors we are reading. Today, for example, I cut out a review of a new film, SEAL Team Six, produced by Harvey Weinstein, one of President Obama's premier corporate backers. Appearing just before the November election, this patriotic docu-drama positions Obama as a strong commander-in-chief who took out the villain of $9 / 11$ and the bête noir of the world. Using conservative tropes familiar to standard Hollywood war films, Democratic partisans deployed representations usually favored by Republicans.

A few weeks earlier, conservative forces had released an anti-labor feature demonizing teacher unions and public schools, Won't Back Down, a \$20-million film produced by billionaire Philip Anschutz. However, despite glamorous stars (Maggie Gyllenhall, Viola Davis, Holly Hunter), an enormous advertising budget, and an opening in over 2500 theaters nationwide, the film was a dismal flop, unlike the political documentary favoring charter schools two years before, Davis Guggenheim's Waiting for Superman, which became a cause celebre. Enormous sums have flowed into the making of such representations from famous billionaires in America-Gates, Broad, Bezos, the Walton family, Bloomberg, the Koch brothers-who want to privatize public schools and budgets, and replace unionized teachers with low-wage recent college graduates (the Teach for America model).

Yet another example of discourse as a battleground involves a federal tax report secretly withdrawn because of Republican objections. The news story (November 2, 2012, New York_Times) reported that the non-partisan Congressional Research Service found "no correlation between top tax rates and economic growth," refuting a major claim by Republicans and Romney that high tax rates on the super-rich are bad for recovery and prosperity. This data-based report was forced out of "circulation," one of the four functional involvements of rhetoric in society, according to my first framework above.

These items are typical of the specific illustrations of theory I constantly search for and hand out in class or post online, posing them as problems, asking students to apply 
concepts from our readings or from my initial frameworks to explain them, and ask how particular situations reflect theories or tenets of Occupy.

Lastly, we follow news of Occupy 2.0-what campaigns are activists pursuing now? Calendars of activities reach me weekly via "Inter-Occupy" which I share in class and online. One group of Occupiers is opposing hydraulic fracking in New York State. Another is supporting immigrant bakery workers in New York City. A third is at work on housing issues; a fourth on debt. Students attended a series of events in NYC involving Occupy and reported back to the seminar.

The great questions are: Can this disparate activity come together as it did in 2011 for a consolidated, mass challenge to inequality? What are the means to make this happen? What did Occupy do well and what did it do poorly? What lessons can be drawn from the successes and failures? Such issues preoccupy many, but no one yet has the answer. Those activists who strode into Zuccotti Park Sept 17, 2011 thought they would be quickly evicted by police or thrown out after the first night. They did not expect to stay 59 days and provoke massive interest. Yet, it all came to pass, so much so that OWS was constantly trying to catch up to events it had provoked, as were authorities whose militarized police solved the crisis for them, for now. Obviously, the vast problems of the $99 \%$ are still unresolved; the vast theft of national treasure by the $1 \%$ continues with the blessing of both major parties. Such conditions of aggressive class war being waged by the rich has been underway for over 30 years, creating the eruptions at Zuccotti and elsewhere. The unrelenting class war (as well as a race war on dark-skinned people, especially young Blacks) will continue to drive opposition forward and if we do our work well, we will learn how to take it farther, deeper, and larger next time. Academic courses can contribute to such learning. 